\title{
Michael Sandel, Przeciwko udoskonalaniu człowieka. Etyka w czasach inżynierii genetycznej, Wydawnictwo Kurhaus Publishing, Warszawa 2014, pp. 125
}

I $\mathrm{n}$ recent decades an increase of the meaning of bioethical cases in political debates could be observed. They have been started in 1970 by Roe $v$. Wade abortion case and, since then, included topics such as euthanasia, in vitro fertilization, and human enhancement. A common feature of all these cases is that they all, more or less, concern the matter of life, death, and human nature. That feature is also the main source of mutual misunderstanding between debating people because they all base their arguments, convictions, and judgements on different concepts of life, death, and human nature. For some of them, life is God's gift and death is a moment when God takes a human's soul away. In this group, some claim that if life comes from God, it would be wrong to manipulate it by, e.g. genetic engineering, while the others claim that if life is a gift, hence it belongs to us, we should use it to the maximum and make it better. Obviously, there are other people who argue that death is not a moment, but a process, and that presupposition lets them seek for criteria and arguments in favour of euthanasia or earlier organ transplantations. Irrespective of the case we choose to discuss, we can notice that in all biopolitical debates people represent different rationalities, hence use different arguments that not always match each other. For instance, it is very likely that a person who uses arguments referring to religious beliefs represents illogical, dogmatic or paradigmatic rationality while a person who uses secular arguments represents any other kind of rationality or dogma/paradigm in the aforementioned ones. The outcome however is always the same. If both sides of debate represent different rationalities, they cannot reach the point of mutual consensus. Nevertheless, some authors argue that the problem lies not in the variety of rationalities and that reaching the consensus would be possible if we had more explicit arguments to use in biopolitical debates.

One of these authors is a famous American political philosopher, Michael Sandel. Although he is known mainly for his lectures on justice and communitarian 
criticism of liberalism, he had an episode (2002-2005) in The President's Council on Bioethics (PCBE) where he has met other famous authors who shared his anxieties about the use of biotechnology, such as Francis Fukuyama or Leon Kass. Initially, a scientific result of Sandel's participation in PCBE was a short essay on genetic engineering but being convinced by his colleagues Sandel extended it and published it as a book about genetic engineering, its place in the modern societies and political deliberations upon it. The reviewed here Przeciwko udoskonalaniu czlowieka (its original title is The Case Against Perfection - for the sake of linguistic coherence I will be using it in the remainder), however, is not entirely a new stage in Sandel's work. It is rather a peculiar continuation, though concerning the new topics, of his previous thoughts present in Democracy's Discontent: America in Search of a Public Philosophy (1998), Liberalism and the Limits of Justice (1998), Public Philosophy: Essays on Morality in Politics (2005) and some kind of a starting point to his next books: Justice: What's the Right Thing to Do? (2010) and What Money Can't Buy: The Moral Limits of Markets (2012). For the sake of simplicity we can say that Sandel's main idea in all his works basically remained the same, that if we are by nature encumbered to any kind of community, there is no possibility that we could always make free, independent and "conscious" choices, and that made him perceiving a community and preserving it as valuable. What was different, however, was how Sandel argued his conviction.

In The Case Against Perfection the author proposed us two things: to assume that biotechnological procedures do not raise any of our moral disagreements and to look not at the biotechnological means but at aims to which the means are used. Then he asked us to consider if and, if yes, how these procedures deprive us our freedom and humanity (p. 31). In more general terms, Sandel's main aim in the reviewed book was to help us express our anxieties about the long-term social or political goals of using biotechnology in the form of wellconstructed, bioconservative argumentation that would share a common ground of rationality with transhumanists' (or other bioliberals') argumentation and could firmly stand against it. Did he succeed?

To answer this question we have to assume that it can be answered positively only if the author was able to elaborate other kind of argumentation than the one based on intuitions, i.e. irrational fears. It is that way because in the biopolitical debates "bioconservatives hold that we should honour intuitions about the special value of being human, even if we cannot identify reasons to ground those intuitions" (Roache, 2001). Yet at the very beginning of the book, the author has made the task harder to himself by claiming that the argument of autonomy is insufficient in biopolitical debates (because it is based on the false premise that children who are not enhanced are always able to make free and independent choices). So, what did he propose to overcome this theoretical obstacle? In the five chapters referring to the different topics concerning various applications of human enhancement techniques Sandel deliberated on the shape of societies pursuing children enhancement (chapters 1 and 3), possible changes in our perception of sport disciplines (chapter 2) and changes of our attitudes towards other people assuming that we had an enhancement procedure (chapters 4 and 5). The author started his task by answering to an apparently simple question. What is the 
difference between medical treatment that requires a genetic modification of human body and a procedure that is focused only on improving someone's body and capabilities? We could answer that the difference is in the initial intention of having such a procedure, but the possible outcomes eventually remain a mystery. Sandel however seemed to be more daring in predicting them. He claimed that the permission to use enhancements always leads to the rise of two groups of people - those who have and those who have not an access to the enhancing technology. In his opinion, it always causes that people lose their humanity. Why? The author tried to explain it on the example of sportsmen. According to him, we admire their unusual capabilities and an effort they take to win a competition, but, first of all, we admire their congenital talents. Using technology to equalise sportsmens' chances would make us admire the artistry of pharmacists, says Sandel, instead of the natural talents of athletes (p. 33). However, the central point of Sandel's argument of losing humanity concerned not that that people will become equal but a fear that the possible increase of inequality between them will cause a decrease of meaning of three social values they all share, namely humility, responsibility, and solidarity (p. 79). The author argued that we are not able to be humble if we can control risk factors present in our lives; and that we cannot be responsible for our successes if we achieved them due to enhancements. Finally, he argued that we are solidary only if we cannot achieve a chosen aim individually, hence being perfect and able to act separately would certainly deprive us the potentiality of being solidary.

The reviewed book had a great potential of becoming the first serious theo- retical opposition to the claims of transhumanists and other bioliberals. This potential, however, was wasted in the moment in which Sandel introduced the categories of life as a gift and giftedness. The author was aware that "speaking of a gift presupposes a giver” (p. 84) and that the "giver" is unambiguously identified as God. Hence, to prove his arguments as valid means to prove the existence of God in the first place. Sandel tried to overcome this theoretical obstacle by claiming that appreciating the value of life as a gift is possible even without presuming that the giver is God. We cannot, however, accept this claim because it obviously is a logical fallacy, a classical petitio principi. Unfortunately for the argumentation in the book, it was almost entirely based on that premise. One can ask if one logical mistake can ruin all the author's effort? Usually no but the case of the reviewed book was different from the very beginning. Let me remind that Sandel's main aim in The Case Against Perfection was to propose the argumentation that would be based on the other premises than the "intuitive" ones. Meanwhile, not only the main assumption but all arguments in the book are based on more or less general intuitions and irrational fears about the future. The additional proof to that statement is that the author many times stated that although he tried to explain why we feel anxious about using biotechnology, it usually was not possible (p. 17, 19, 21, 24, 29, 31, 48, 60, 77, 84, 85, 86). Therefore, the realisation of Sandel's main goal was a failure, though not entirely. The author certainly helped us to understand the bioconservative way of reasoning in political debates on human enhancement cases, and then the bioconservative thinking in general. In my opinion, the latter fact alone is sufficient 
enough to recommend the book to every person interested in the upcoming changes of our understanding what is political. Also, Sandel's book can certainly serve as a guide to religious believers how to declare their anxieties about human enhancement more clearly. But the greatest importance of Sandel's work is that it explicitly expresses a need of creating arguments that would be based less on intuitive and more on rational grounds, so they could be used to accurately defend the bioconservative beliefs and interests in the present and upcoming biopolitical debates.

\section{References:}

Roache, R. (2009). Bioconservatism, Bioliberalism, and the Wisdom of Reflecting on Repugnance. Monash Bioethics Review, 28(1), 4.1-4.21. 